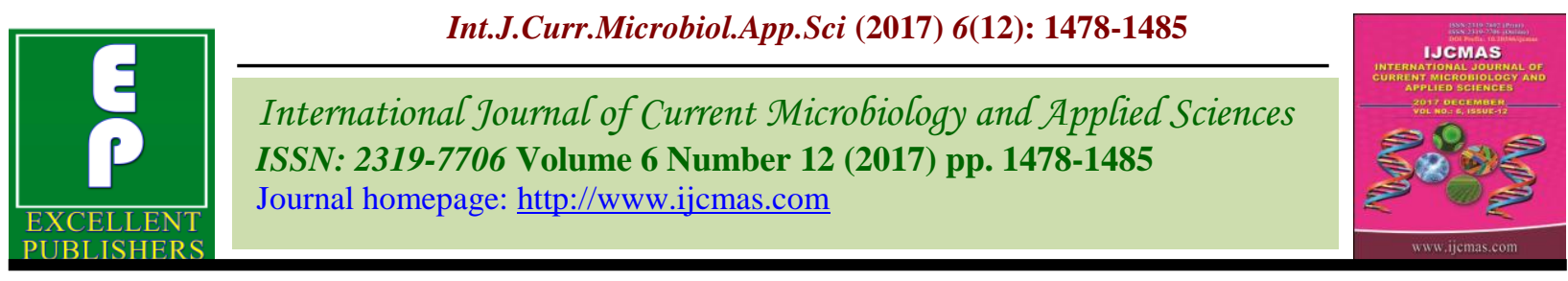

Original Research Article

https://doi.org/10.20546/ijcmas.2017.612.164

\title{
Correlation and Path Analysis in Bottle Gourd [Lagenaria siceraria (Mol.) Standl.]
}

\author{
Padmakshi Thakur $^{1 *}$, J. Singh ${ }^{1}$, S.K. Nair ${ }^{2}$ and Sasmita Priyadarsini Dash ${ }^{1}$ \\ ${ }^{1}$ Department of Vegetable Science, IGKV, Raipur-492012 (C.G.), India \\ ${ }^{2}$ Department of Genetics and Plant Breeding, IGKV, Raipur-492012 (C.G.), India \\ *Corresponding author
}

\section{A B S T R A C T}

\begin{tabular}{|l|}
\hline K e y w o r d s \\
$\begin{array}{l}\text { Correlation, Path co- } \\
\text { efficient, Character } \\
\text { association, Yield and } \\
\text { bottle gourd. }\end{array}$ \\
\hline Article Info \\
\hline $\begin{array}{l}\text { Accepted: } \\
\text { 12 October } 2017 \\
\text { Available Online: } \\
\text { 10 December } 2017\end{array}$ \\
\hline
\end{tabular}

An experiment was carried at Research cum Instructional farm of Horticulture, Department of Vegetable Science, IGKV, Raipur during kharif season (2015). Correlation and path analysis among different characters of seventy three bottle gourd genotypes were studied. Observations were recorded for the characters viz., days to first male and female flower appearance, node number at which first male and female flower appears, days to $50 \%$ flowering, days to fruit set, number of branches per plant, days to first fruit harvest, fruit length $(\mathrm{cm})$, average fruit weight $(\mathrm{g})$, fruit girth $(\mathrm{cm})$, number of fruits per plant, fruit yield (q per ha) and crop duration. Correlation and path studies revealed that number of fruits per plant and average fruit weight had highest significant positive association with yield $\mathrm{q}$ per ha at both phenotypic and genotypic levels and also had significant positive direct effect on fruit yield q per ha.

\section{Introduction}

Bottle gourd [Lagenaria siceraria (Mol.) Standl.] is one of the most important cucurbit grown throughout the country for its tender fruits. It is also known as white flowered gourd or calabash gourd. It is a fast growing winter seasonal climbing annual, native to Africa. It is grown in both rainy and summer seasons and its fruits are available in the market throughout the year. It is a monoecious and highly cross-pollinated crop known to good potential for yield components.

Yield is a complex character influenced by several genetic factors interacting with environment. Success of any breeding programme for its improvement depends on the existing genetic variability in the base population and on the efficiency of selection. For a successful selection, it is necessary to study the nature of association of the character in question with other relevant traits and also the genetic variability available for them. Path coefficient provides a better index for selection rather than correlation coefficient by separating the correlation coefficient of yield and its components into direct and indirect effects. Therefore, the present study was undertaken with the objective to understand the character association among the various traits and their direct and indirect effects on yield in bottle 
gourd. The information on such aspects can be of great help in formulating appropriate breeding strategy for genetic upgradation of this crop.

\section{Materials and Methods}

The study was carried out during kharif season (2015) at Research cum Instructional farm of horticulture, Department of Vegetable Science, IGKV, Raipur. The experiment comprised of seventy three genotypes of bottle gourd. The experiment was laid out in a Randomized Block Design with three replications at $3.0 \times 0.75 \mathrm{~m}$ row to row and plant to plant spacing. All the recommended cultural practices were adopted to raise a healthy crop. Data were recorded on five randomly selected plants with respect to characters viz., days to first male and female flower appearance, node number at which first male and female flower appears, days to $50 \%$ flowering, days to fruit set, number of branches per plant, days to first fruit harvest, fruit length $(\mathrm{cm})$, average fruit weight $(\mathrm{g})$, fruit girth $(\mathrm{cm})$, number of fruits per plant, fruit yield ( $\mathrm{q} / \mathrm{ha}$ ) and crop duration. The data were subjected to analysis of variance as per the procedure described by Panse and Sukhatme (1985). Correlation and path coefficients were calculated according to method suggested by Miller et al., (1958) and Dewey and Lu (1959) respectively.

\section{Results and Discussion}

The analysis of variance (Table 1) showed significant differences for all the characters under study. This analysis of variance revealed that mean sum of squares due to genotypes was highly significant for all characters. Significant mean sum of squares due to fruit yield and attributing characters revealed existence of considerable variability in material studied for improvement for various traits.
The correlation between fruit yield $\mathrm{q}$ per ha with different yield attributes are presented in Table 2. Yield (q/ha) expressed a highly significant positive correlation with no. of fruits per plant and fruit weight at both phenotypic and genotypic levels respectively, whereas it showed significant negative correlation with duration of crop at genotypic and phenotypic levels. Prasad et al., (1993), Narayan et al., (1996), Kumar and Singh (1998), Hawlader et al., (1999), Umamaheswarappa et al., (2004) and Raja et al., (2006) reported very high and significant correlation coefficient for fruit weight and no. of fruit per plant with yield. This indicates that fruit yield in bottle gourd can be improved by direct selection of fruit characters like number of fruits per plant and fruit weight. The positive correlation between the desirable characters is favourable to the plant breeder because it helps in simultaneous improvement of all the characters.

Highly significant and positive correlation was shown by node number at which first male flower appears with node number at which first female flower appears, days to first male flower appearance, days to first female flower appearance, days to $50 \%$ flowering, days to fruit set, days to first fruit harvest, fruit girth, number of branches per plant and duration of crop at phenotypic and genotypic level, respectively. Node number at which first female flower appears had highly positive and significant correlation with days to first male flower appearance, days to first female flower appearance, days to $50 \%$ flowering, days to fruit set, days to first fruit harvest, fruit girth and duration of crop at both genotypic and phenotypic levels.

Days to first male flower appearance had highly positive and significant correlation with days to first female flower appears, days to $50 \%$ flowering, days to fruit set, days to first fruit harvest and fruit girth at both 
genotypic and phenotypic levels. Days to first female flower appearance had highly positive and significant correlation with days to $50 \%$ flowering, days to fruit set, days to first fruit harvest and fruit girth at both genotypic and phenotypic levels and it is also significant and positively correlated with duration of crop only at genotypic level.

Table.1 Analysis of variance for fruit yield and its component characters in bottle gourd

\begin{tabular}{|c|c|c|c|c|}
\hline \multirow{2}{*}{$\begin{array}{c}\text { S. } \\
\text { No. }\end{array}$} & \multirow[b]{2}{*}{$\begin{array}{c}\text { Character } \\
\text { (df) }\end{array}$} & \multicolumn{3}{|c|}{ Mean sums of square } \\
\hline & & $\begin{array}{c}\text { Replication } \\
\text { (2) }\end{array}$ & \begin{tabular}{|c|} 
Treatment \\
$(72)$
\end{tabular} & Error \\
\hline 01 & $\begin{array}{l}\text { Node no. at which } 1^{\text {st }} \text { male flower } \\
\text { appears }\end{array}$ & 16.35 & $121.09^{* *}$ & 0.878 \\
\hline 02 & $\begin{array}{l}\text { Node no. at which } 1^{\text {st }} \text { female flower } \\
\text { appears }\end{array}$ & 0.96 & $209.44 * *$ & 1.11 \\
\hline 03 & Days to $1^{\text {st }}$ male flower appearance & 12.02 & $146.75^{* *}$ & 2.15 \\
\hline 04 & Days to $1^{\text {st }}$ female flower appearance & 0.98 & $142.62 * *$ & 2.4 \\
\hline 05 & Days to $50 \%$ flowering & 0.65 & $158.41^{* *}$ & 0.97 \\
\hline 06 & Days to fruit set & 6.61 & $146.00 * *$ & 1.72 \\
\hline 07 & Days to $1^{\text {st }}$ fruit harvest & 64.9 & $142.06 * *$ & 3.18 \\
\hline 08 & Fruit length $(\mathrm{cm})$ & 10.69 & $91.42 * *$ & 6.41 \\
\hline 09 & Fruit girth $(\mathrm{cm})$ & 4.43 & $92.29 * *$ & 13.48 \\
\hline 10 & Average fruit weight (g) & 984.81 & $148454.9^{* *}$ & 6854.18 \\
\hline 11 & No. of fruits per plant & 1.06 & $15.83 * *$ & 1.93 \\
\hline 12 & No. of branches per plant & 1.36 & $9.90 * *$ & 0.22 \\
\hline 13 & Duration of crop (sowing to last harvest) & 2.75 & $198.30^{* *}$ & 13.73 \\
\hline 14 & Yield (q/ha) & 1004.12 & $5071.63 * *$ & 205.26 \\
\hline
\end{tabular}

$*$ : Significant at $5 \%, * *$ : significant at $1 \%$ 
Table.2 Genotypic and phenotypic correlation coefficients between fruit yield and its component characters in bottle gourd (Kharif, 2015-16)

\begin{tabular}{|c|c|c|c|c|c|c|c|c|c|c|c|c|c|c|c|}
\hline & & 01. & 02. & 03. & 04. & 05. & 06. & 07. & 08. & $\begin{array}{l}09 . \\
\end{array}$ & 10. & 11. & 12. & 13. & 14. \\
\hline Char & acters & $\begin{array}{l}\text { Node no. at } \\
\text { which } 1^{\text {st }} \\
\text { male flower } \\
\text { appears }\end{array}$ & $\begin{array}{l}\text { Node no. at } \\
\text { which } 1^{\text {st }} \\
\text { female flower } \\
\text { appears }\end{array}$ & $\begin{array}{l}\text { Days to } 1^{\text {st }} \\
\text { male } \\
\text { flower } \\
\text { appear- } \\
\text { ance }\end{array}$ & $\begin{array}{l}\text { Days to } 1^{\text {st }} \\
\text { female } \\
\text { flower } \\
\text { appear- } \\
\text { ance }\end{array}$ & $\begin{array}{c}\text { Days to } 50 \% \\
\text { flowering }\end{array}$ & $\begin{array}{l}\text { Days to } \\
\text { fruit set }\end{array}$ & $\begin{array}{l}\text { Days to } \\
1^{\text {st }} \text { fruit } \\
\text { harvest }\end{array}$ & $\begin{array}{c}\text { Fruit } \\
\text { length } \\
(\mathrm{cm})\end{array}$ & $\begin{array}{c}\text { Fruit } \\
\text { girth }(\mathrm{cm})\end{array}$ & $\begin{array}{l}\text { Average } \\
\text { fruit } \\
\text { weight } \\
(\mathrm{g})\end{array}$ & $\begin{array}{c}\text { No. of } \\
\text { fruits per } \\
\text { plant }\end{array}$ & $\begin{array}{c}\text { No. of } \\
\text { branches } \\
\text { per plant }\end{array}$ & $\begin{array}{c}\text { Duration of } \\
\text { crop (sowing } \\
\text { to last } \\
\text { harvest) }\end{array}$ & $\begin{array}{l}\text { Yield (q } \\
\text { /ha) }\end{array}$ \\
\hline & $\mathrm{P}$ & 1.000 & $0.767 * *$ & $0.644 * *$ & $0.635 * *$ & $0.708 * *$ & $0.667 * *$ & $0.675^{* *} *$ & -0.061 & $0.292 * *$ & $0.148 *$ & -0.063 & $0.240 * *$ & $0.319 * *$ & -0.067 \\
\hline 01. & $G$ & 1.000 & $0.779 * *$ & $0.665 * *$ & $0.657 * *$ & $0.722 * *$ & $0.684^{* *}$ & $0.696 * *$ & -0.056 & $0.362 * *$ & $0.157 *$ & -0.075 & $0.248 * *$ & $0.347 * *$ & -0.076 \\
\hline & $\mathrm{P}$ & & 1.000 & $0.589 * *$ & $0.619 * *$ & $0.672 * *$ & $0.645 * *$ & $0.646 * *$ & $-0.159 *$ & $0.296 * *$ & 0.088 & $-0.187 * *$ & $0.169 *$ & $0.333 * *$ & $-0.169 *$ \\
\hline 02. & $\mathrm{G}$ & & 1.000 & $0.606 * *$ & $0.640 * *$ & $0.683 * *$ & $0.661 * *$ & $0.669 * *$ & $-0.180 * *$ & $0.365 * *$ & 0.102 & $-0.224 * *$ & $0.174 * *$ & $0.376^{* *}$ & $-0.183 * *$ \\
\hline & $\mathrm{P}$ & & & 1.000 & $0.844 * *$ & $0.889 * *$ & $0.859 * *$ & $0.840 * *$ & 0.003 & $0.304 * *$ & 0.031 & -0.103 & $0.154 *$ & 0.111 & -0.083 \\
\hline 03. & $\mathrm{G}$ & & & 1.000 & $0.881 * *$ & $0.923 * *$ & $0.888 * *$ & $0.887 * *$ & 0.002 & $0.364 * *$ & 0.039 & -0.126 & $0.162 *$ & 0.118 & -0.091 \\
\hline & $\mathrm{P}$ & & & & 1.000 & $0.896 * *$ & $0.968 * *$ & $0.911 * *$ & -0.072 & $0.324 * *$ & 0.042 & $-0.141^{*}$ & 0.096 & $0.205^{* *}$ & -0.122 \\
\hline 04. & $\mathrm{G}$ & & & & 1.000 & 0.930 ** & $0.982 * *$ & $0.954 * *$ & -0.078 & $0.408 * *$ & 0.047 & $-0.192 * *$ & 0.108 & $0.232 * *$ & -0.129 \\
\hline & $\mathrm{P}$ & & & & & 1.000 & $0.908 * *$ & $0.867 * *$ & 0.001 & $0.301 * *$ & 0.031 & -0.123 & 0.117 & $0.145^{*}$ & $-0.133^{*}$ \\
\hline 05. & $G$ & & & & & 1.000 & $0.934 * *$ & $0.907 * *$ & -0.01 & $0.374 * *$ & 0.025 & $-0.156^{*}$ & 0.126 & $0.173 *$ & $-0.141 *$ \\
\hline & $\mathrm{P}$ & & & & & & 1.000 & $0.930 * *$ & -0.054 & $0.350 * *$ & 0.023 & $-0.164 *$ & 0.063 & $0.186 * *$ & $-0.141 *$ \\
\hline 06. & $\mathrm{G}$ & & & & & & 1.000 & $0.964 * *$ & -0.061 & $0.437 * *$ & 0.027 & $-0.213^{* *}$ & 0.07 & $0.211^{* *}$ & $-0.150^{*}$ \\
\hline & $\mathrm{P}$ & & & & & & & 1.000 & -0.007 & $0.346 * *$ & 0.03 & $-0.189 * *$ & 0.131 & $0.199 * *$ & -0.13 \\
\hline $0 \%$ & $\mathrm{G}$ & & & & & & & 1.000 & -0.015 & $0.433 * *$ & 0.022 & $-0.207 * *$ & $0.133 *$ & $0.231 * *$ & $-0.135^{*}$ \\
\hline & $\mathrm{P}$ & & & & & & & & 1.000 & $-0.254 * *$ & 0.042 & 0.11 & -0.048 & -0.085 & 0.076 \\
\hline 08. & $\mathrm{G}$ & & & & & & & & 1.000 & $-0.376^{* *}$ & 0.052 & $0.154 *$ & -0.062 & -0.078 & 0.067 \\
\hline 09 & $\mathrm{P}$ & & & & & & & & & 1.000 & 0.052 & 0.017 & $0.191 * *$ & 0.013 & 0.057 \\
\hline 09. & $\mathrm{G}$ & & & & & & & & & 1.000 & 0.057 & 0.025 & $0.222 * *$ & 0.031 & 0.055 \\
\hline & $\mathrm{P}$ & & & & & & & & & & 1.000 & $0.684 * *$ & 0.103 & -0.115 & $0.687 * *$ \\
\hline 10. & $\mathrm{G}$ & & & & & & & & & & 1.000 & $0.888 * *$ & 0.12 & -0.119 & $0.777 * *$ \\
\hline & $\mathrm{P}$ & & & & & & & & & & & 1.00 & $0.141 *$ & $-0.312 * *$ & $0.760 * *$ \\
\hline 11. & $\mathrm{G}$ & & & & & & & & & & & 1.00 & $0.215 * *$ & $-0.398 * *$ & $0.956 * *$ \\
\hline 12 & $\mathrm{P}$ & & & & & & & & & & & & 1.000 & $0.167 *$ & 0.096 \\
\hline 12. & $\mathrm{G}$ & & & & & & & & & & & & 1.000 & $0.181 * *$ & 0.104 \\
\hline & $\mathrm{P}$ & & & & & & & & & & & & & 1.000 & $-0.429 * *$ \\
\hline 13. & $\mathrm{G}$ & & & & & & & & & & & & & 1.000 & $-0.495 * *$ \\
\hline 14. & $\mathrm{P}$ & & & & & & & & & & & & & & 1.000 \\
\hline & $\mathrm{G}$ & & & & & & & & & & & & & & 1.000 \\
\hline
\end{tabular}


Table.3 Direct and indirect effect of component character on fruit yield in bottle gourd (kharif, 2015-16)

\begin{tabular}{|c|c|c|c|c|c|c|c|c|c|c|c|c|c|c|}
\hline Characters & $\begin{array}{c}\text { Node no. at } \\
\text { which } 1^{\text {st }} \\
\text { male } \\
\text { flower } \\
\text { appears }\end{array}$ & $\begin{array}{c}\text { Node no. } \\
\text { at which } \\
1^{\text {st }} \text { female } \\
\text { flower } \\
\text { appears }\end{array}$ & $\begin{array}{l}\text { Days to } \\
1^{\text {st }} \text { male } \\
\text { flower } \\
\text { appear- } \\
\text { ance }\end{array}$ & $\begin{array}{c}\text { Days to } \\
1^{\text {st }} \\
\text { female } \\
\text { flower } \\
\text { appear- } \\
\text { ance }\end{array}$ & $\begin{array}{c}\text { Days to } \\
50 \% \\
\text { flowering }\end{array}$ & $\begin{array}{c}\text { Days } \\
\text { to fruit } \\
\text { set }\end{array}$ & $\begin{array}{l}\text { Days to } \\
1^{\text {st }} \text { fruit } \\
\text { harvest }\end{array}$ & $\begin{array}{l}\text { Fruit } \\
\text { length } \\
(\mathrm{cm})\end{array}$ & $\begin{array}{l}\text { Fruit } \\
\text { girth } \\
(\mathrm{cm})\end{array}$ & $\begin{array}{l}\text { Average } \\
\text { fruit } \\
\text { weight } \\
\text { (g) }\end{array}$ & $\begin{array}{l}\text { No. of } \\
\text { fruits } \\
\text { per } \\
\text { plant }\end{array}$ & $\begin{array}{c}\text { No. of } \\
\text { branches } \\
\text { per plant }\end{array}$ & $\begin{array}{c}\text { Duration } \\
\text { of crop } \\
\text { (sowing to } \\
\text { last } \\
\text { harvest) }\end{array}$ & $\begin{array}{l}\text { Yield (q } \\
\text { /ha) }\end{array}$ \\
\hline $\begin{array}{l}\text { Node no. at which } 1^{\text {st }} \\
\text { male flower appears }\end{array}$ & $\underline{0.060}$ & 0.008 & 0.219 & -0.329 & -0.124 & -0.043 & 0.144 & 0.013 & -0.121 & 0.010 & 0.071 & 0.016 & -0.006 & -0.083 \\
\hline $\begin{array}{l}\text { Node no. at which } 1^{\text {st }} \\
\text { female flower appears }\end{array}$ & 0.047 & $\underline{0.011}$ & 0.200 & -0.320 & -0.118 & -0.042 & 0.138 & 0.033 & -0.117 & 0.008 & -0.054 & 0.013 & -0.007 & -0.209 \\
\hline $\begin{array}{l}\text { Days to } 1^{\text {st }} \text { male } \\
\text { flower appearance }\end{array}$ & 0.040 & 0.006 & $\underline{0.329}$ & -0.441 & -0.160 & -0.056 & 0.183 & 0.001 & -0.121 & 0.017 & 0.090 & 0.011 & -0.002 & -0.101 \\
\hline $\begin{array}{l}\text { Days to } 1^{\text {st }} \text { female } \\
\text { flower appearance }\end{array}$ & 0.040 & 0.007 & 0.290 & $\underline{-0.500}$ & -0.162 & -0.062 & 0.197 & 0.015 & -0.126 & 0.001 & 0.117 & 0.007 & -0.004 & -0.181 \\
\hline $\begin{array}{l}\text { Days to } 50 \% \\
\text { flowering }\end{array}$ & 0.043 & 0.007 & 0.304 & -0.467 & $\underline{-0.174}$ & -0.059 & 0.187 & 0.004 & -0.126 & 0.004 & 0.150 & 0.008 & -0.003 & -0.120 \\
\hline Days to fruit set & 0.041 & 0.007 & 0.293 & -0.491 & -0.163 & $\underline{-0.063}$ & 0.199 & 0.012 & -0.140 & -0.001 & 0.115 & 0.005 & -0.004 & -0.191 \\
\hline $\begin{array}{l}\text { Days to } 1^{\text {st }} \text { fruit } \\
\text { harvest }\end{array}$ & 0.042 & 0.007 & 0.292 & -0.477 & -0.158 & -0.061 & $\underline{0.206}$ & 0.005 & -0.140 & -0.009 & 0.098 & 0.009 & -0.004 & -0.189 \\
\hline Fruit length $(\mathrm{cm})$ & -0.005 & -0.002 & -0.003 & 0.045 & 0.005 & 0.005 & -0.006 & -0.164 & 0.106 & 0.033 & 0.029 & -0.004 & 0.001 & 0.040 \\
\hline Fruit girth $(\mathrm{cm})$ & 0.022 & 0.004 & 0.119 & -0.188 & -0.066 & -0.027 & 0.086 & 0.052 & -0.334 & -0.042 & 0.238 & 0.007 & -0.001 & -0.130 \\
\hline $\begin{array}{l}\text { Average fruit weight } \\
\text { (g) }\end{array}$ & -0.002 & 0.000 & -0.018 & 0.002 & 0.002 & 0.000 & 0.006 & 0.018 & -0.045 & $\underline{0.310}$ & 0.075 & -0.004 & 0.002 & $0.346 *$ \\
\hline No. of fruits per plant & 0.008 & -0.001 & 0.054 & -0.106 & -0.047 & -0.013 & 0.037 & -0.009 & -0.144 & -0.042 & $\underline{0.552}$ & 0.010 & 0.005 & $0.302 * *$ \\
\hline $\begin{array}{l}\text { No. of branches per } \\
\text { plant }\end{array}$ & 0.015 & 0.002 & 0.054 & -0.053 & -0.022 & -0.004 & 0.029 & 0.010 & -0.034 & 0.020 & 0.083 & $\underline{0.065}$ & -0.003 & 0.160 \\
\hline $\begin{array}{l}\text { Duration of crop } \\
\text { (sowing to last } \\
\text { harvest) }\end{array}$ & 0.021 & 0.004 & 0.039 & -0.116 & -0.029 & -0.013 & 0.048 & 0.013 & -0.025 & 0.038 & -0.165 & 0.013 & $\underline{-0.018}$ & -0.191 \\
\hline
\end{tabular}

Residual value: 0.0654, Diagonal and bold underline figures shows direct effect on fruit yield 
Days to $50 \%$ flowering exhibited highly significant and positive correlation with days to fruit set, days to first fruit harvest and fruit girth at both phenotypic and genotypic level. It also showed significant and positive correlation with no. of fruits per plant at genotypic level only.

Days to fruit set had highly positive and significant correlation with days to first fruit harvest and fruit girth at both genotypic and phenotypic level. Days to first fruit harvest showed highly positive and significant correlation with fruit girth at both phenotypic and genotypic level and with duration of crop only at genotypic level. Highly significant and negative correlation of days to fruit length was observed with fruit girth at phenotypic and genotypic levels. Fruit girth showed significant and positive correlation with no. of fruits per plant at both phenotypic and genotypic levels.

The findings clearly indicated that genotypic correlations were of higher magnitude to the corresponding phenotypic ones, thereby establishing strong inherent relationship among the characters studied. The low phenotypic value might be due to appreciable interaction of the genotypes with the environments. An overall observation of correlation coefficient analysis revealed that number of fruits per plant and fruit weight exhibited the significant positive correlation with yield quintal per ha. Hence, direct selection for these traits may lead to the development of high yielding genotypes of bottle gourd. The present findings are in conformity with Ahmed et al., (2005) who reported that fruit yield $\mathrm{q}$ per ha had strong positive association with number of fruits per vine, fruit weight, fruit length and fruit girth. Similar results were also reported by Wani et al., (2008), Kumar et al., (2012), Singh et al., (2012), Bhardwaj et al., (2013) and Mandal et al., (2015).
Path coefficient analysis depicts the effects of different independent characters individually and in combination with other character on fruit yield. The data on path coefficient analysis at genotypic level showing direct and indirect effects of significant characters over yield q per ha is tabulated in Table 3 . The data revealed that no. of fruits per plant showed the highest positive direct effect $(0.552)$ on fruit yield followed by days to first male flower appearance (0.329), average fruit weight (0.310), days to first fruit harvest (0.206), number of branches per plant (0.065), node number at which first male flower appears (0.060) and node no. at which first female flower appears (0.011) whereas, days to first female flower appearance $(-0.500)$, fruit girth (-0.334), days to $50 \%$ flowering ($0.174)$, fruit length (-0.164), days to fruit set $(-0.063)$ and duration of crop (-0.018) showed negative direct effects on fruit yield q per ha.

In present investigation number of fruits per plant and average fruit weight showed significant positive and direct effect on fruit yield q per ha. Therefore, plant having more number of fruits with average fruit weight should be considered in selection criteria for increasing fruit yield. Directly or indirectly all characters showed positive effect on fruit yield, which is in confirmation to the finding of Umamaheswarappa et al., (2004), Husna et al., (2011) and Janaranjani and Kanthaswamy (2015) reported that number of fruits vine ${ }^{-1}$ had maximum direct effect on fruit yield followed by fruit weight. Similar results were obtained by Singh et al., (2006), Muralidharan et al., (2013) and Thakur et al., (2015). Positive direct effect of various characters on total fruit yield observed in the present study are according to the findings of Narayan et al., (1996) and Kumar and Singh (1998) for days to the first harvest and number of fruits per plant, Hawlader et al., (1999) for number of female flowers per plant, Ahmed et al., (2005) for average fruit 
weight, number of fruits per plant and fruit length, Singh et al., (2006) for female flower per vine, average fruit weight, number of fruits per vine, Gayen and Hossain (2007) for average fruit weight and fruit length.

The results of the study indicated that the characters with positive correlation have shown high direct effects. Thus, number of fruits per plant had high direct and correlation values. The effect of residual factor (0.0654) on fruit yield ( $\mathrm{q} / \mathrm{ha}$ ) was negligible, thereby, suggested that no other major yield component is left over.

\section{References}

Ahmed, N., Hakeem, Z. A., Singh, A. K. and Baseerat, A., 2005. Correlation and path coefficient analysis in bottle gourd. Haryana J. Hort. Sci., 34(1/2): 104-106.

Bhardwaj, D. R., Singh, A. and Singh, U., 2013. Genetic variability of bottle gourd [Lagenaria siceraria (Mol.) Standl.] by multivariate analysis. Published in Proc. Of National Symposium On Abiotic and Biotic Stress management in Vegetable Crops. Ind. Soc. Veg. Sci. 370.

Dewey, D. R. and Lu, K. H., 1959. A correlation and path coefficient analysis of components of crested wheat grass seed production. Agron. J., 51: 512-515.

Gayen, N. and Hossain, M., 2007. Correlation and path analysis in bottle gourd [Lagenaria siceraria (Mol.) Standl.]. Environment and Ecology. 25(1): 193195.

Hawlader, M. S. H., Haque, M. M. and Islam, M. S., 1999. Variability, correlation and path analysis in bottle gourd. Bangladesh J. of Scientific and Indust. Res. 34(1): 50-54.

Husna, A., Mahmud, F., Islam, M. R., Mahmud, M. A. A. and Ratna, M., 2011. Genetic variability, correlation and path co-efficient analysis in Bottle
Gourd [Lagenaria siceraria (Mol.)

Standl.]. Ad. Bio. Res. 5(6): 323-327.

Janaranjani, K. G. and Kanthaswamy, V., 2015. Correlation studies and path analysis in bottle gourd. J. of Horticulture. 2(1).

Kumar, A., Singh, B., Kumar, V., Singh, M. K. and Singh, K. V., 2012. Correlation and path coefficient analysis for certain metric traits in bottle gourd [Lagenaria siceraria (Mol.) Standl.] using line $\times$ tester analysis. Annals Horti. 5(1): 9094.

Kumar, S. and Singh, S. P., 1998. Correlation and path coefficient analysis for certain metric traits in bottle gourd [Lagenaria siceraria (Mol.) Standl.]. Vegetable Science. 25(1): 40-42.

Mandal, J., Tirumalesh, M. and Dhangrah, V. K., 2015. Studies on genetic variability and trait inter-relationship in Bottle gourd [Lagenaria siceraria (Mol.) Standl). Hort. Flora Research Spectrum. 4(1): 34-38.

Miller, P. A., Williams, J. E., Robinson, H. F. and Comstock, R. E., 1958. Estimates of variance and co-variance in upland cotton and their implications in selection. Agron. J., 50: 126-131.

Muralidharan, B., Kanthaswany, V. and Sivakumar, B., 2013. Correlation and path analysis studies in bottle gourd [Lagenaria siceraria (Mol.) Standl.]. Published in Proc. Of National Symposium On Abiotic and Biotic Stress management in Vegetable Crops. Ind. Soc. Veg. Sci., 69.

Narayan R., Singh S. P., Sharma D. K. and Rastogi K. B., 1996. Genetic variability and selection parameters in bottlegourd. Ind. J. Hort., 53(1): 53-58.

Panse, V. G. and Sukhatme, P. V., 1967. Statistical methods for agricultural workers. ICAR, New Delhi. Pp. 97-151.

Prasad, M., Singh, M. and Srivastava, B. P., 1993. Genetic Variability and 
Correlation Studies in bottle gourd. Haryana J. Hort. Sci., 22(3): 222-227.

Raja, S., Bagle, B.G. and Dhandar, D.G., 2006. Identification of yield attributes in bottle gourd for rainfed condition. Vegetable Science. 33(1): 106-108.

Singh, A. K., Pan, R. S. and Bhavana, P., 2012. Correlation and path coefficient analysis for quantitative traits in early season bottle gourd [Lagenaria siceraria (Mol.) Standl.]. Veg. Sci. 39(2): 198-200.

Singh, K.P., Choudhary, D.N., Mandal, G. and Saha, B.C., 2006. Correlation and path analysis in bottle gourd [Lagenaria siceraria (Mol.) Standl.]. J. of Interacademicia. 10(3): 309-313.

Thakur, P., Sharma, D., Visen, V. K. and Dash, S. P., 2015. Character association studies in bot tle gourd [Lagenaria siceraria (Mol.) Standl.]. Progressive Research- An International Journal Society for Scientific Development. 10(1): 459-463.

Umamaheswarappa, P., Krishnappa, K. S., Murthy, P. V., Nagarajappa A. and Muthu, M. P. (2004). Correlation and path coefficient analysis studies in bottle gourd [Lagenaria siceraria (Mol.) Standl.] cv Arka Bahar. Environment and Ecology. 22 (Spl-4): 636-640.

Wani, K. P.; Ahmed, N.; Hussain, K. and Mehfuza Habib Kant, R.H., (2008). Correlation and path coefficient analysis in bottle gourd [Lagenaria siceraria (Mol) Standl.] under temperate condition of Kashmir valley. Environment and Ecology. 26(2A): $822-824$.

\section{How to cite this article:}

Padmakshi Thakur, J. Singh, S.K. Nair and Sasmita Priyadarsini Dash. 2017. Correlation and Path Analysis in Bottle Gourd [Lagenaria siceraria (Mol.) Standl.]. Int.J.Curr.Microbiol.App.Sci. 6(12): 1478-1485. doi: https://doi.org/10.20546/ijcmas.2017.612.164 